\title{
Development of Contemporary Installation Art and Its Application in Public Space
}

\author{
Hui Liu \\ College of Art and Communication, Bohai University, Jinzhou, 121013, China \\ 312587995@qq.com
}

Keywords: contemporary installation art; public space; application

\begin{abstract}
Installation art as a product of human mind and a kind of social economic and cultural activities, reflected the state of the development of social history and culture, shows the perfect combination of science, technology and public space, reflects the essence of human society needs, to satisfy the public's need for spiritual culture. Installation art is a public space and human life with openness and creativity of the mediation, the unique artistic expression and the unique artistic charm, to the masses to different space through experience and life experience. Contemporary art in public space has a very wide range of applications, including fiber installation art, video art, landscape art, interactive installation art, lighting installation art and new media art, etc.
\end{abstract}

\section{Introduction}

Installation art is a contemporary art, which is a new art category under the shadow of postmodern philosophy and aesthetics. Installation art is an extension of people's life experience, and the participation and participation of the audience is part of the installation art. Installation art creation environment, make the audience within a defined space, by passive viewing into active feeling, in addition to positive thinking and body intervention, also want to use visual, hearing, touch, smell and taste. Device art is characterized by misalignment of life. After the dislocations, the audience will be forced to take the easy acceptance of the work and enter the multifaceted understanding process. The materials used are mostly due to the art of daily necessities and industrial products, and the sculpture on the ground, and therefore different from traditional frame art, asked the audience from multiple perspectives and various associative meaning, even from the aspects of work relations with exhibition environment. Installation art genre without limit, free to comprehensive use of painting, touch model, architecture, music, drama, poetry, prose, movie, TV, audio, video and photography [1]. The installation art, colloquially, is a combination of "site + material + emotion".

Public space for residents' daily life and social life refers to the public use of outdoor and indoor space, including streets, squares, parks, sports venues, schools, libraries, and commercial places, etc. Installation art as a product of human mind and a kind of social economic and cultural activities, reflected the development of social history and culture, shows the perfect combination of science, technology and public space, reflects the essence of human society needs, to satisfy the public's need for spiritual culture [2]. As the "people-oriented" development of further research innovation model, installation art as a new form of artistic expression in public space, brought momentum for science and technology innovation, make public space more full of fun, fully mobilize the participation of the public sentiment. Because of the way of thinking, aesthetic tendency and values of the public, more rational, more and more desire for more profound emotional experience. So installation art to traditional design has brought the new vitality, can attract the public attention, to influence public behavior, brought new opportunity for the interactive development of the public space.

\section{Characteristics of Installation Art}

Installation art has the following three characteristics [3]:

(1) The universality of media materials. Open performance and development trend of installation 
art is able to criticize traditional material, want to transcend ourselves, reached a new visual creation, will be bold use of new raw materials. Therefore, the greatest characteristic of installation arts is the comprehensive breakthrough of making materials. The holographic images, smells, lights and lights that represent high tech can be used as new carriers and raw materials. Installation art can using a variety of different materials of raw material, through stimulation of humans other than visual senses, making this art form than ordinary art more rich administrative levels. Through the contrast between material and carrier material, the contradiction difference is formed to achieve more impact artistic effect.

(2) Stereoscopic form. Compared with the ordinary art, installation art don't need to frame and display of a work stipulation, the relationship between itself and the external space are vague, make works of art can exist in a specific space, city and urban residents can be included, opening up the new perspective of space design. Make art, all sorts of wonderful creative ideas through different space design, show the atmosphere of the novel will resonate with the audience, let the people live in are already familiar with the environment, to has found new eyes to see around the world, and through new eyes to look at themselves. In this case, the installation art design not only consider their own in three dimensional space environment, and to break the traditional sculpture, permanent, time, process, their own presence, opportunity, and space environment combined into one entity.

(3) Interdisciplinary integration. Media interactive installation art is a kind of new art language, arrangement of a live audience to participate in the performance and interactive, observe the audience's expression and reaction, a dynamic device combining art and advanced computer technology, computer animation and Volkswagen graphics, images and music, and lighting the collocation of a variety of methods, such as subject to overall performance. New media art USES a variety of methods and linguistic symbols to represent the integrity of vision and the integrity of thematic concepts, and extends the path of expressing ideas. Interactive media installation art works at the beginning of the creation, showcase, and interactive experience to complete the stage, has been in a state of change, in the process of change, which require the participation of the audience and interaction, and at some stage, the audience may also become the creation subject, plays an important role, more reflect the importance of installation art to interact with the audience.

\section{Development of Contemporary Installation}

Installation art emerged in the $1960 \mathrm{~s}$, the period of installation artists to the existing architectural space in a museum to produce strong interest, research and test, the effect of various sources of psychological with psychological space to replace the practical and physical space. At the same time, the installation art began to be closely related to the image technology, which led to the installation of elements such as projection video. The period of installation art is not systematic art types, including environmental art, pour at art, land art, and art, etc., it is under the postmodern thoughts of emerging art and art promote each other the result of [4].

In the 1970s, the installation art began to show a strong, politically oriented work. The installation artists of the period began experimenting with films, television and video. The use of these new visual arts means a better exploration of areas where traditional visual arts cannot be touched. Device art has shown the absurdities of the Internet in this period, which is popular with the lower and lower classes of society. After the advent of television and video technology, the installation art developed further, breaking the traditional form of expression and entering the digital realm.

The remarkable feature of the device art in the 1980s was that television and video were used more widely, and the subject matter was constantly being explored. Western art in the $90 \mathrm{~s}$ theme is more widely, involves many aspects of modern life and thought, especially in the modern age, people care about hot spots, such as environmental protection, the peace of the world, a variety of cultural and ethnic conflicts, etc. People's thought is also during this period by the human rights thought into humanistic thought, social stability, environment, resources and ecological problems are more and more people concern, reflect on their own has been the subject of installation art.

The 21st century is the age of information technology, animation, film and television and new 
media technology such as smart, make installation art expression achieved breakthrough, avant-garde, experimental, ideas and even absurdity are increasingly highlight, one hundred years in the field of art gradually replaced the dominant frame art, become a major means of more and more artists creation. The inclusion of installation art is the mainstream of The Times, which embodies the inclusiveness and cooperation of artistic activities. More and more installation art is used in the design field, frequently appearing in people's life, the installation art becomes the important component of people's life.

\section{Application of Contemporary Installation Art in Public Space}

Installation art is a public space and human life with openness and creativity of the mediation, the unique artistic expression and artistic appeal, to the masses of different space through experience and life experience. Device art is clever, clever, humorous and tactful to express emotion, leading people to think actively and raise the cognition of mind. Installation art is reflect the attitude of individual survival experience and visual language, to choose what kind of media material, more and more flexible and randomness, and connecting with the idea of people and the world around them. The value of art, is the item the historical value and artistic value, so people can produce memories and become infected, the tension of work to help construction and performance of space environment atmosphere, thus will become the protagonist of space theme. Contemporary installation art is widely used in public space, mainly including the following aspects:

(1) Fiber installation art. The art of fiber, which has evolved from ancient tapestry art in the west, is an art form that combines aesthetic value and function. Natural animal plant fiber or synthetic fiber is the main, can show rich visual effect. Various production methods, combined with the reasonable use of material, make the fiber art into buildings, produce the beauty of harmony, and conform to the requirements of the people's aesthetic and visual experience. A lot of fiber art works has broke through the traditional form, to develop in the direction of installation art, makes the fiber art more expressive and summoned, and produced a strong contemporary fiber art [5]. Fiber art fiber materials as the main material, from the perspective of installation art, combined with the artist's aesthetic view, method of installation art craft, the product of the artistic processing of space environment.

(2) Image installation art. The art form of the imaging device art in the public space is summarized into three types: first, the image device and the construction fit, construct the artistic landscape. From the simple display screen, the development of imaging equipment for the form of landscape modeling, it has become a new language of architectural design, and architectural landscape with the flavor of the times. Second, the night projection device, wake up memory for the history given new ideas. The use of nighttime projection to awaken people's memory of the building and thinking, to promote people to actively commemorate the past historical events and construction sites themselves. Third, multi-screen image device, quasi-sculpture method creates multi-dimensional space. The static space becomes dynamic space, and the non - directional space becomes the space with obvious spatial and temporal orientation [6].

(3) Landscape installation art. The progress of the times makes the modern landscape design become a complex system of interdisciplinary. Landscape installation art is the application of installation art on the alienation of space and shape the site, the use of materials and technical design means to create a sense of experience and spiritual implication of the landscape, so that the outdoor space in the exchange of more prominent, people and landscape more closely linked Together [7]. The art of landscape installation integrates the art of "sensibility" into the "rational" landscape design, and finds a more reasonable basis for the installation of the art of installation. It also introduces the art of "sensibility" in the "rational" landscape design, Design to bring a wide range of design ideas, the two phases with each other. Landscape art is the art of creation in three-dimensional space, and the relationship with the site is very close, the relationship with people more closely, rather than let people feel the art of passive.

(4) Mirror device art. With the increasing demand for landscape space and the combination of installation art and landscape, landscape design can start from the characteristics of mirror art, to 
explore the diversity of space atmosphere to create. Mirror material for mirrors, including both ordinary mirrors and materials that have been subjected to technical processing to form bright, reflective images. In the mirror installation art, the designer will be based on different design requirements and different material properties, create a different artistic effect. Sometimes the artist wants the mirror to be smooth and clear, reflecting the surroundings; sometimes with curved mirrors to create a strange visual experience [8]. With the people in-depth understanding of the installation of art, mirror device art unique visual expression of tension, from the color, texture and materials and other aspects of the decoration of the urban landscape space, so that the city landscape space into a visual focus.

(5) Interactive device art. Interactive device art is based on computer graphics technology, computer information collection, computer information processing and computing technology, a variety of information input and output carrier as a hardware device, the use of various materials to the integrated installation of the space for the scene platform, To interact with the exchange of information as the main form of art. The viewer does not accept the work passively, but takes the initiative to participate in the exchange, and even into the works, become part of the work [9]. Interactive art in the way of experience and innovation, breaking the traditional form of artistic creation, embodies the technical and artistic integration of the unity of each other. Interactive device art used in public space design, has a rich interest, attention to human emotions, embodies the times and art, to meet people's psychological needs, highlighting the contemporary values and aesthetics.

(6) Lighting equipment art. Vision is the perception of the object's reflection of light, light reshaping the image of the object of the actual situation changes, breaking the minds of people in the material image and the traditional concept of visual laws. Lighting art is lighting as an art medium, through different intensity, quality and color of light, adding scientific and technological elements, to the viewer to bring a different visual, auditory and psychological feelings. Lighting equipment has become at the forefront of the era of fashion art, is the representative of the intelligent landscape device, the language of light as a purely formal language creation. Lighting art can be independent of the creation of the main body, can also be combined with other forms of art, into the aesthetic point of view, for the audience to bring different artistic effects [10]. With the rapid development of science and technology, lighting equipment, the tension and expression of the arts have produced a qualitative leap in the art to achieve innovation and breakthrough.

(7) New Media Installation Art. New media technology refers to the modernization of digital technology, network technology, and communication technology and other new technologies as the basis, to provide users with the necessary information services, media means. New media device art is the product of new media technology and device art cooperation, is a new media technology, multi-dimensional works of art, can also be a transformation and audience perception of space. The new media installation art has the following characteristics [11]: efforts to create a place where the audience exposure to the atmosphere, the use of conventional or unconventional sound and light electrochemical and other means to stimulate the audience to participate in interest, may change with the change of circumstances, so that the audience Can be multi-angle appreciation, the works are mainly used for exhibition rather than collection. The practical application of the new media installation art includes the field of cultural protection, exhibition display field, advertising media field and disabled public welfare field.

\section{Conclusion}

The art of installation as a new form of art is constantly evolving. The development of the installation art has its inherent factors: on the one hand, the whole of contemporary international art development is stimulating and promoting the art of our country. On the other hand, the development of science and technology and the change of aesthetic concept, Show a trend of modern diversification. Therefore, the installation of art in our country not only has broad prospects for development, for the development of world art also has a very far-reaching significance. The art of installation contributes to the culture of space and the shaping of art. The installation of art in the space is a very good means of cultural and artistic communicating it can be in the spirit of the 
people, to enhance people's artistic accomplishment. Art helps to improve the environmental quality of space. Device art helps in space interaction and communication. From the attention to appreciation, people with the understanding of the installation of art, contribute to the inclusion of space environment.

\section{References}

[1] L. S. Liang, "The research of contemporary installation art," Master's degree of Tianjin University of Technology, 2007.

[2] X. L. Deng, Y. C. Li, "Application of installation art in urban public space," Beauty and times, vol. 30, no. 7, pp. 80-82, 2015.

[3] Academic hall, "The concept and characteristics of installation art," http://www.lunwenstudy.com/jsp/111056.html, 2017-3-12.

[4] Y. C. Jiang, X. L. Fan, "On the background of the development of contemporary urban installation art," Beauty \& Times, vol. 5, no. 9, pp. 77-78, 2016.

[5] C. F. Zheng, "Application of fiber art installation in space," Master's degree of Jilin Architecture University, 2015.

[6] H. Liu, "Video installation art and its application in the public space," Master's degree of Beijing Institute Of Fashion Technology, 2011.

[7] Y. Zhang, "The use research of landscape installation art in urban public space," Master's degree of Southeast University, 2015.

[8] Y. Chen, X. L. Fan, "The construction of the space atmosphere in the urban landscape," Art Science and Technology, vol. 29, no. 12, pp. 300-301, 2016.

[9] R. Deng, "On the Application of Interactive Installation Art in Urban Public Space," Master's degree of Hefei Polytechnic University, 2014.

[10] Y. J. Chen, "Lighting installation art in the context of contemporary Art," http://news.artron.net/20160919/n868720.html, 2017-4-17.

[11] F. Sha, "The research of contemporary installation art," Master's degree of Nanjing arts institute, 2015. 